\title{
Logistic and environmental quality
}

\section{Yogeeswari Subramaniam}

Azman Hashim International Business School (AHIBS), Universiti Teknologi Malaysia (UTM), Johor, Malaysia; email: yogees.wari@yahoo.com.my

Keywords: Logistic Performance, Environmental Quality, Panel Data Analysis

\begin{abstract}
Logistic performance has been improved tremendously in many parts of the world. Nonetheless, its improvement does not necessarily guarantee that environmental quality can be preserved. Hence, it is the objective of this study to examine the effect of logistic improvement on environmental degradation in developing countries. Applying dynamic panel model estimator for a panel of 50 developing countries for the period between 2010 and 2016, this study observes that the level of pollution tends to be higher with a higher level of logistic performance. The findings show that developing countries that did not adopt green practices on logistic performance pose negative effects in terms of air pollution, climate change, and global warming. Thus, the efforts to reduce environmental degradation must be comprehensive enough and the priority of environmental policies should be in the first place, targeting logistic performance. In other words, performance measure of logistic should also take into account its contribution to environmental quality.
\end{abstract}

\section{Introduction}

Environmental issue is a critical problem currently facing many countries across the globe. Air pollution, water pollution, soil and land pollution, deforestation, increased carbon footprint and so on are among the environmental concerns which need immediate attention as they affect everyone, either human or animal. As result, natural disasters are seen to happen more often nowadays in the form of flash floods, tsunamis and cyclones. ${ }^{1}$ Table 1 shows several cases connected to several environmental issues across the globe with some of the cases are without proper mitigation policies installed.

Although of the potential explanations of the issues are mentioned in Table 1 such as industrialization, urbanization, non-renewable energy and deforestation, we also suspect that logistic may also contribute to environmental quality in the negative way if the applauded green logistic is not fully implemented. While the direction of the effect is ambiguous as logistic can have positive and negative implications on environmental quality, surprisingly there are limited studies examining this issue empirically. Theoretically, logistic expansion may trigger deforestation and invite more private transports, leading to degradation of environmental quality. ${ }^{2}$ On the positive note, if improvement of logistic services involves activities such as increasing number of public

\footnotetext{
${ }^{1}$ According to conserve-energy-future.com, there are 25 critical areas of environmental issues, apart from those listed here. Envirotech-online.com shares almost the same point with the top 5 environmental concerns are biodiversity, water, deforestation, pollution and climate change.

${ }^{2}$ Fuel-based carbon footprint. For instance, EIA (2018) estimates that transportation is accounted for $8 \mathrm{Gt}^{\mathrm{CO}_{2}}$ or $1 / 4$ of total emissions in 2016 at global scale, which is more than 70 percent larger than its contribution in 1990. Moreover, $\mathrm{CO}_{2}$ emissions, which is due to freight transportation constitute more than 40 percent of total transport-related $\mathrm{CO}_{2}$ emissions. Worryingly, the contribution is expected to further increase in 2050 to 60\% (Manners-Bell, 2015; EIA, 2017).
} 
services (i.e. rail and bus) as well as renewable energy-based services, environmental damage due to the expansion of logistics services may be minimized. Hence, it is the objective of this study to examine the implication of improvement in logistic performance on environmental quality in developing countries.

Table 1: Some cases of environmental damages and the available solutions

\begin{tabular}{|c|c|c|}
\hline No & Case & Suggested solution(s) \\
\hline 1. & $\begin{array}{l}\text { Air pollution in the most densely } \\
\text { populated Mexico City. }\end{array}$ & $\begin{array}{l}\text { i. Limit how often Mexican can drive } \\
\text { ii. Enforce strict emissions inspections }\end{array}$ \\
\hline 2. & $\begin{array}{l}\text { Air pollution in the UK due to } \\
\text { automobile smoke and factory exhaust }\end{array}$ & $\begin{array}{l}\text { i. Banning the burning of coal } \\
\text { ii. Encouraging the use of public } \\
\text { transports and cleaner fuels. }\end{array}$ \\
\hline 3. & $\begin{array}{l}\text { Acid rain in Canada due to wind which } \\
\text { bringing the pollution from factories } \\
\text { across Canada and the USA. }\end{array}$ & No clear solutions so far. \\
\hline 4. & $\begin{array}{l}\text { Nuclear disaster in Ukraine (1986), } \\
\text { leading to the release of radioactive } \\
\text { material to water and soil. }\end{array}$ & $\begin{array}{l}\text { No clear solution. Regional as well as } \\
\text { global debate on how nuclear waste to be } \\
\text { disposed is continuing. }\end{array}$ \\
\hline 5. & $\begin{array}{l}\text { Water pollution in African countries } \\
\text { due to pesticides, fertilizers, human } \\
\text { waste, mining and manufacturing } \\
\text { byproducts. }\end{array}$ & No active solution is available. \\
\hline
\end{tabular}

6. Deforestation as nearly $90 \%$ of the No active solution can be seen. coastal rainforests in West Africa have been cut down since 1990s.

Note: We fully rely on the source in stating the suggested solutions. We might be overlooked the most recent solutions being practiced. Source: [1]

The OECD Environmental Outlook to 2030 projected that the global emissions of greenhouse gasses (GHGs) to grow by $37 \%$ to $52 \%$ in 2050 [2]. This could result in an increase in global temperature over pre-industrial levels in the range of $1.7-2.4^{\circ}$ Celsius by 2050 , leading to increased heat waves, droughts, storms and floods, and resulting in severe damage to key infrastructure and crops. GHGs are primarily driven by 76 percent growth in carbon dioxide emission and 16 percent growth in methane emission. The sources of GHGs emissions are electricity and heat, agriculture, manufacturing and construction and forestry, which come from burning fossil fuels, coal and natural gas [3].

On other development, logistics have significantly contributed to economic growth, growth of employment and the development of a world market, accounting for 9 percent of global GDP [4]. While the rise in logistics activities has contributed positively to economic growth, it is also responsible for nearly one-quarter of GHG emissions. Logistic is the second-largest source of GHG emissions, with around 2.8 of million metric tons of the global GHG emission [5]. As shown by Figure 1, roughly $4.95 \%$ of the total emissions was from transportation and $0.55 \%$ from logistic facilities. The largest share of GHG emissions in this sector is expected from heavy-duty vehicle (bus, truck), light-duty 
vehicles (cars, van) and followed by aircraft, rail, ships and boats emissions. Therefore, transport can also be among the main contributor to GHGs emissions.

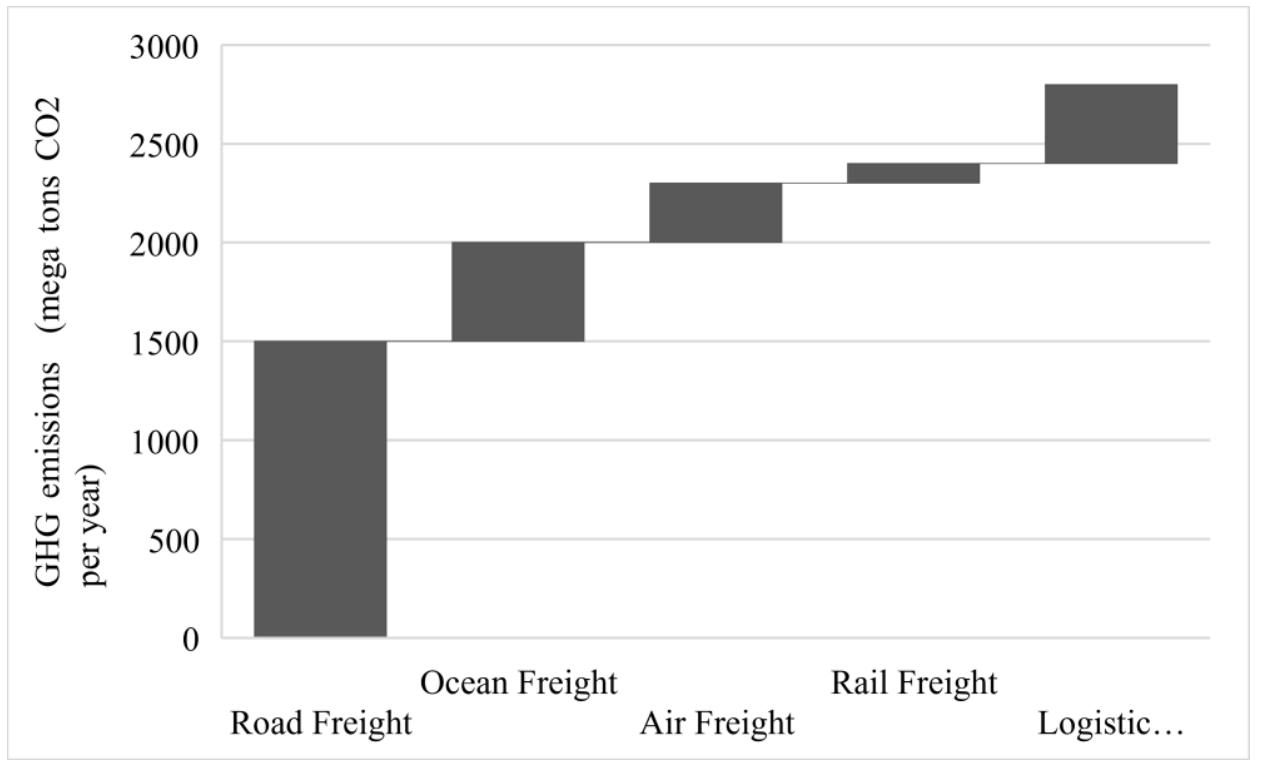

Figure 1. GHG emission of logistic sector Source: IPCC (2011)

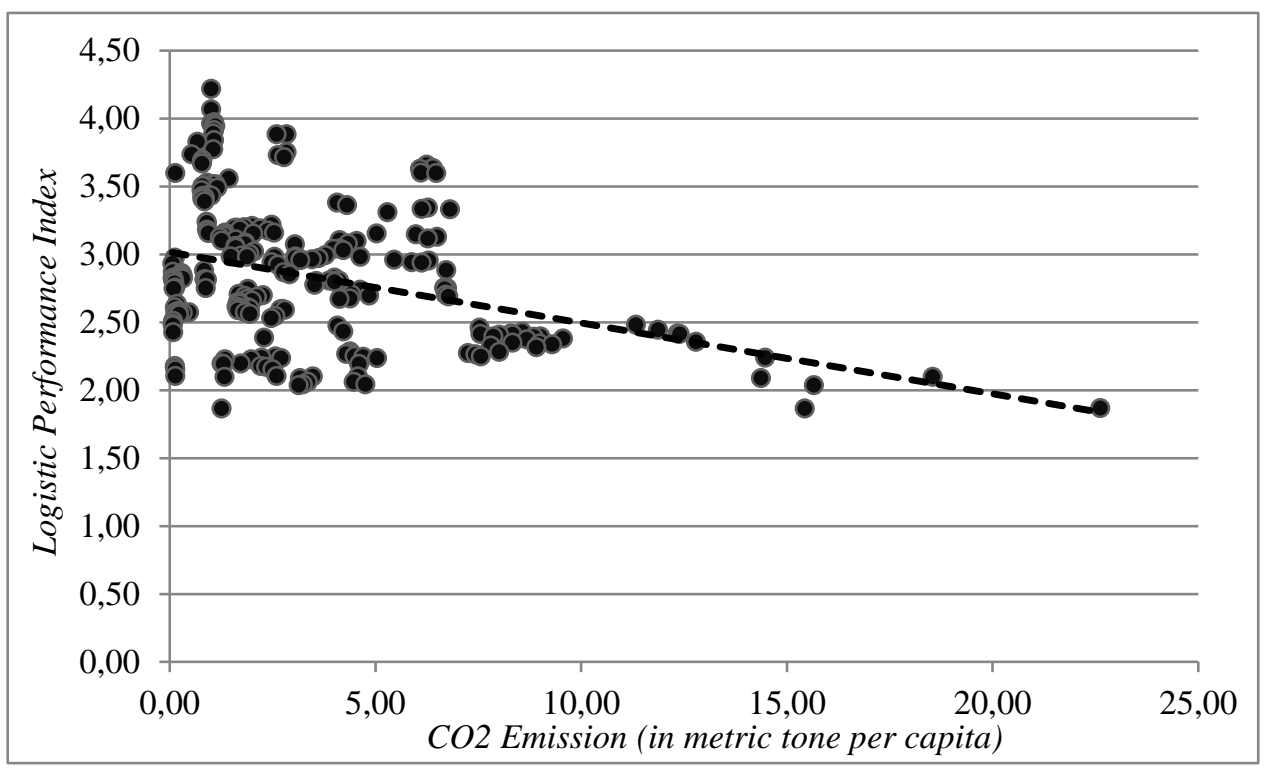

Figure 2. $\mathrm{CO}_{2}$ emission vs Logistic Performance Index ${ }^{3}$ of 50 developing countries ${ }^{4}$ Note: the downward line represents the simple regression line. Source:[6].

3 The index ranges from 1 to 5 , with a higher score representing better performance.

${ }^{4}$ Indonesia, Mongolia, Philippines, Vietnam, Malaysia, Thailand, Armenia, Tajikistan, Ukraine, Uzbekistan, Albania,Azerbaijan,Belarus,Bulgaria,Georgia,Kazakhstan,Macedonia, Montenegro, Romania, Russian Federation, Serbia, Turkey, Bolivia, El Salvador, Honduras, Argentina, Belize, Brazil, Colombia, Costa Rica, Dominican Republic, Ecuador, Jamaica, Mexico, Panama, Paraguay, Peru, Venezuela, Egypt, Nepal, Bangladesh, Bhutan, India, Sri Lanka, Ethiopia, Guinea, Mozambique, Uganda, Mauritania and Namibia. 
Figure 1 highlights the trend of logistic performance and $\mathrm{CO}_{2}$ emission of 50 developing countries in 2016, the sample for this study. What really interesting is that declining in logistic performance is automatically accompanied by deterioration in environmental quality. Figure 1 signifies that the amount of $\mathrm{CO}_{2}$ emission of 50 developing countries is increasing gradually over the periods of 2016. Thus, the relationship between logistic and $\mathrm{CO} 2$ emission or the proxy of environmental degradation is likely to tell us that as countries experience decreasing trend of logistic performance, they will have a tendency to suffer less carbon emission simultaneously. As suggested by [7], improper management and unawareness of the environmental implications of logistic operations may significantly lead to reckless application of logistic and bring in more $\mathrm{CO} 2$ emissions. In other words, current practices of logistic operation are likely failed to incorporate environmental protection strategy. As a result, it may generate a negative impact on the environment by offering various destructions on air and water pollutions, climate change and global warming. Even if logistic can offer solution to environmental degradation, that may come indirectly through Kuznets curve. Improvement of logistic performance may indicate that economic growth can be stimulated. High income generated by high economic growth may imply environmental protection in the long run as predicted by environmental Kuznets curve. Economic development will increase awareness among the people to embark on a more environmentally sustainable logistics, such as redesigning sourcing, distribution systems and managing reverse logistics where it can give a positive impact on the environment [7]. For example, Mexico and Brazil shows that total logistic performance index has been growing between 2010 and 2016, while the total emission has declined for the same period, as expected. With two contradicting possible connections between logistic performance and environmental degradation, further investigation about them is very crucial. ${ }^{5}$

Moreover, the linkages between income and environmental degradation, as well as renewable energy consumption has been intensively analyzed empirically. The first strand of the literature focuses on environmental degradation and income, which refer to testing the validity of the Environmental Kuznet Curve (EKC) hypothesis. [8-15] claim that EKC hypothesis is valid. The EKC hypothesis states that the linkage between economic growth and environment resembles an inverted-U curve. EKC postulates that environmental degradation rises as a country starts to develop or when income level is still at low level. However, income will start to bring in a decrease in environmental degradation as it passes a turning point of certain high-income level. On other note, [9] and [12] observe that the relationship between environmental degradation and economic growth may appear linear-shape, u shape or any other shapes (the opposite of the EKC). Hence, based on these studies, we can synthesize from the past studies that income significantly affects environmental degradation.

The second strand of analyses tries to link renewable energy consumption and environment ([16]; [17]; [15]; [18]). [16], [17], [15] and [18] show that renewable

\footnotetext{
${ }^{5}$ Although Kuznets curve suggests a straightforward or automatic solution to environmental issue, hardly this is happening in developing countries. Among the suggested reason is corruption (Masron and Subramaniam, 2018).
} 
energy has the capabilities to make a significant impact on reducing environmental pollution over the time. For instance, [19] and [20] find that renewable energy consumption contributes to the reduction in emission, especially for developed countries. Moreover, [17] explore the relationship between renewable energy consumption and environmental degradation in OECD countries. Based on the results, [17] conclude that increases in renewable energy consumption will significantly decrease the emissions, especially for these OECD countries. In the nutshell, this study summarizes that there is a negative effect of renewable energy on environmental degradation.

Although the majority of past studies focus on income and renewable energy, we believe that logistic performance can and should also play an important role in altering environmental quality, especially in developing countries. Most of the past studies on logistics are mainly focusing on the acceptance of green logistics [21], determinants of green logistics (see [22]), and its implication on firms' performances ([23];[24];[25]). Very limited studies deal with how logistic affect environmental sustainability with exception to a few studies such as [26], and [7]. Although there are various suggestions by past studies as mentioned above which urge logistic firms' activities to be greener, not much is known regarding its current level of greenness or environmentally friendly since the level of green itself is difficult to be measured. While we do expect certain degree of responses by firms to transform their logistic activities to be environmentally friendly, the actual implication on environmental quality is yet to be confirmed.

Notwithstanding the benefits from improvement in logistic performance, there is a growing concern that the performance of logistic is not always consistent with the principle of environmental sustainability. This is because logistic activities mainly depend on fossil fuel consumption, which generates greater emission that can damage the environment and become a primary source of climate change. [2] points out that carbon dioxide emissions from transport activities could increase by $60 \%$ by 2050 and by $160 \%$ from global freight alone. Thus, improper management and lack of awareness of the environmental impact of logistics performance may significantly reduce environmental quality. Thereby, this study tries to examine this issue by answering whether the current logistic performance in developing countries is enough to match the term "green logistic".

The organization of this study is as follows: section 2 provides the research methodology, including model specification and the estimation strategy. The empirical results discussions are reported in section 3 and finally, section 4 concludes the article.

\section{Methodology}

In standard economic theory, it is widely recognized that EKC hypothesis can be specified in a standard quadratic relation between environmental degradation and income. We further augment the basic model by incorporating the factor that have been suggested by past studies, namely renewable energy consumption ([15], among others) as controlled variables. In short, our basic empirical model is as follows:

$$
\ln E D_{i t}=\delta_{0}+\delta_{1} \ln I N C_{i t}+\delta_{2} \ln I N C_{i t}^{2}+\delta_{3} \ln R E_{i t}+\varepsilon_{i t}
$$


where subscript $t$ refers to year and $i$ denotes country, ED is environmental degradation, INC is income and INC $^{2}$ is income square, and finally, RE is renewable energy consumption. The prefix " $I n$ " represents the natural logarithm and $\varepsilon_{i t}$ is error term. Accordingly, the presence of EKC is verified by $\delta_{1}$ being significantly positive and $\delta_{2}$ is significantly negative. To examine our central focus that logistic performance can be a potential determining factor of environmental degradation, we augment Eq. (1) by adding the measure of logistic performance. With the inclusion of logistic performance, our final model will be:

$$
\ln E D_{i t}=\delta_{0}+\delta_{1} \operatorname{lnIN} C_{i t}+\delta_{2} \operatorname{lnINC} C_{i t}^{2}+\delta_{3} \ln R E_{i t}+\delta_{4} L P_{i t}+\varepsilon_{i t}
$$

On the estimation procedure, we utilize the dynamic panel models approach, namely dynamic panel GMM estimator to analyze the impact of logistic performance on environmental degradation. In this case, the dynamic GMM equation of the model is shown using Eq. (3) below:

$$
\ln E D_{i t}=\delta_{0}+\gamma \ln E D_{i t-1}+\delta_{1} \ln I N C_{i t}+\delta_{2} \operatorname{lnINC} C_{i t}^{2}+\delta_{3} \ln R E_{i t}+\delta_{4} L P_{i t}+\varepsilon_{i t}
$$

Firstly, the first differences GMM are applied in order to wipes out the country-specific effect or any time-invariant country-specific variable [27]. Unfortunately, the first difference GMM estimator neglects the potential information in the level relationship and in the relations between the levels and the first differences [28]. To overcome this condition, [29] recommend the first difference GMM regression further combined with an estimator in levels to produce a system, which is known as a system-GMM estimator. [30] indicate that there are two different statistics such as serial correlation and Hansen test are used in these regressions to examined the validity of the GMM estimator. The serial correlation test tests the null hypothesis of no first-order serial correlation and no second order serial correlation in the residuals of the first differenced equation. Rejection of the null of the absence of the first-order serial correlation $A R(1)$ and failure to reject the absence of the second-order serial correlation $A R$ (2) are valid and the models are correctly specified. The second is the Hansen Test of over-identifying restrictions which is used to examine the overall validity of the instruments by comparing the moment's conditions with their sample analogue.

\begin{tabular}{|c|c|c|c|}
\hline Variables & Proxy & Descriptions & Sources \\
\hline $\begin{array}{l}\text { Environmental } \\
\text { degradation }\end{array}$ & $\begin{array}{l}\text { Carbon Dioxide } \\
\text { emissions }\end{array}$ & Metric Tons Per Capita & \\
\hline Income & GDP per capita & Constant USD & \\
\hline $\begin{array}{l}\text { Renewable } \\
\text { energy }\end{array}$ & $\begin{array}{l}\text { Percentage Of Total } \\
\text { Final Energy } \\
\text { Consumption }\end{array}$ & $\begin{array}{l}\text { Percentage Of Total Final } \\
\text { Energy Consumption }\end{array}$ & [6] \\
\hline $\begin{array}{l}\text { Logistic } \\
\text { performance }\end{array}$ & $\begin{array}{l}\text { Logistics } \\
\text { performance }\end{array}$ & $\begin{array}{l}\text { Index of logistics } \\
\text { performance }\end{array}$ & \\
\hline
\end{tabular}

Table 2: List of Variables, Descriptions and Sources 
For the sample, we used the panel data sample of 50 developing countries over the periods of 2010 to $2016 .{ }^{6}$ Thus, the lists of variables and their sources are presented in Table 2.

\section{Results and Discussion}

The results of descriptive analysis for the variables, namely income, renewable energy, logistic performance and environmental degradation are summarized in Table 3. The mean of environmental degradation is noted as 0.452 , while the minimum and maximum value are 3.237and 2.692, respectively. Renewable energy is between 0.143 and 4.564, with a mean of 3.053. For income, the maximum value is 9.595 and the minimum value is 5.282 and its mean stood at 7.921. Predominantly, the logistic performance index has the mean, minimum and maximum value of $1.046,0.531$ and 1.440 respectively. Overall, the standard deviation displays that environmental degradation has the greatest variation of 1.311 and followed by renewable energy, income and logistic performance.

Table 3. Descriptive Statistics

\begin{tabular}{lllll}
\hline Variable & Mean & Std. Dev. & Min & Max \\
\hline$L E D$ & 0.452 & 1.311 & 3.237 & 2.692 \\
$L Y$ & 7.921 & 1.013 & 5.282 & 9.595 \\
$L R E$ & 3.053 & 1.089 & 0.143 & 4.564 \\
LLP & 1.046 & 0.169 & 0.531 & 1.440 \\
\hline
\end{tabular}

Table 4 presents the results of correlation analysis among the panel series. On the correlation outputs, expected environmental degradation is positively correlated with income and logistic performance index. This result is consistent with that of [13], [14] and [15], as they showed that more income growth increase degradation for the panel of developing countries. The correlation between renewable energy and environmental deterioration is negative ([16]; $[15] ;[18])$.

Table 4. Correlation Analysis

\begin{tabular}{lcccc}
\hline & LED & LY & LRE & LLP \\
\hline$L E D$ & 1.000 & - & - & - \\
$L Y$ & 0.834 & 1.000 & - & - \\
$L R E$ & -0.772 & -0.486 & 1.000 & - \\
$L L P$ & -0.043 & 0.055 & 0.101 & 1.000 \\
\hline
\end{tabular}

From the Table 5, the consistency of the GMM estimator depends on two specification tests, namely serial correlation and Hansen tests. Firstly, failure to reject the null

${ }^{6}$ To be precise, the period employed is 2010, 2012, 2014, and 2016. 
hypothesis of the Hansen test suggests that the instruments are valid and the model is correctly specified. Secondly, we reject the null of the absence of the first order serial correlation and fails to reject the absence of the second order serial correlation. GMM approach's scalar value statistics are used to discuss the better estimators of GMM, failure to reject the null hypothesis of a level moment validity has supported SYS-GMM estimator dominance compared to DIFF-GMM. This study, therefore, adopts SYS-GMM as the main and preferred empirical estimator.

Table 5. Regression Analysis IV $\quad[D V=L E D]$

\begin{tabular}{|c|c|c|c|c|}
\hline & \multicolumn{2}{|c|}{ One-Step } & \multicolumn{2}{|c|}{ Two-Step } \\
\hline & DIFF-GMM & SYS-GMM & DIFF-GMM & SYS-GMM \\
\hline \multirow[t]{2}{*}{$L E D_{t-1}$} & $0.214 * * *$ & $0.990 * * *$ & $0.138^{* * *}$ & $0.981 * * *$ \\
\hline & {$[2.70]$} & {$[4.88]$} & {$[2.38]$} & {$[5.48]$} \\
\hline \multirow{2}{*}{$L Y$} & $0.739 *$ & $4.476 * * *$ & $1.417 * * *$ & $0.979 * * *$ \\
\hline & {$[1.75]$} & [3.97] & {$[3.30]$} & {$[3.14]$} \\
\hline \multirow{2}{*}{$L Y^{2}$} & $-0.945^{*}$ & $-0.425 * * *$ & $-1.021 * * *$ & $-0.378 * * *$ \\
\hline & {$[-1.68]$} & {$[-3.90]$} & {$[-2.38]$} & {$[-3.08]$} \\
\hline \multirow{2}{*}{$L R E$} & -0.010 & $-0.013 * *$ & $-0.030 *$ & $-0.019 * *$ \\
\hline & {$[-1.59]$} & {$[-2.13]$} & {$[-1.98]$} & {$[-2.19]$} \\
\hline \multirow{3}{*}{$L L P$} & $0.7402 *$ & $0.104 * *$ & $0.993 * *$ & $0.080 * * *$ \\
\hline & {$[1.92]$} & {$[2.28$} & {$[2.16]$} & {$[3.07]$} \\
\hline & \multicolumn{4}{|c|}{ Model Criteria } \\
\hline Hansen & 0.630 & 0.277 & 0.630 & 0.277 \\
\hline$A R(1)$ & $0.004 * * *$ & $0.012 * *$ & $0.026 * *$ & $0.012 * *$ \\
\hline$A R(2)$ & 0.504 & 0.645 & 0.765 & 0.897 \\
\hline Diff-Sargan & - & 0.933 & - & 0.945 \\
\hline
\end{tabular}

Note: Asterisks *,**, and*** denotes significant at $10 \%, 5 \%$, and $1 \%$ level respectively.

Figures in [ ] stand for $t$-statistics. The values of Hansen and AR stand for $p$-value.

From Table 5, we find that income (INC) has positive impact on environmental degradation (ED) which is consistent with [14], [15] and [31]. Whereas the estimated coefficient of squared term of income $\left(I N C^{2}\right)$ has a negative sign, which suggests that there is inverted u-shaped income-environment relationship. In other words, it suggests that the quality of environment worsens at the low level of income and then improve as income rises. Among others, our findings are in line with [12], [28], and [32]. Besides that, our finding is inconsistent with [33] and [34], who argue that $U$ - shaped curve which is opposite of EKC is exists instead of EKC and conclude that theory of EKC is not valid for Malaysia and developed contemporary economics (Australia, Denmark, Finland, Japan, Sweden). As a result, this study concludes that the EKC hypothesis exists and implies that pollution is not persistent with economic growth. This result supports the fact that economic growth will initially lead to increase pressure on environmental resources through scale effect. In scale effect, more production of material output will take place and it requires more input and resources in the production process. The increment in production will result in more wastes emissions and tend to destroy the environment [8]. 
At last, technique effect explains the downturn of the EKC curve as a country wealth increasing through continued economic growth, it can afford to invest more on Research and Development (R\&D). These will lead to further technologies progress which will be an instrument for implement friendly and cleaner production techniques, thus it will improve the environmental quality [35]. Therefore, higher income may imply higher concern about environmental quality and more fund is available to formulate degradation prevention strategy. ${ }^{7}$

Our study also finds that renewable energy consumption has a negative significant impact on ED in the developing countries. The result for renewable energy consumption is consistent with past studies, such as [17], [32], [18] and [16]. The increased usage of renewable energy will minimize the deterioration of the environment by not emitting too many emissions. Also, better development and size of renewable energy in a country may also mean a lower rate of dependence on imported oil, increase in the supply of secure and cleaner energy, and offer low carbon-intensive energies. Accordingly, it has been agreed that the global switched from non-renewable to renewable energy are able to avoid the unlimited environmental degradation efficiently. For instance, with highly efficient of cook stoves and advanced biomass system, we may reduce the level of traditional biomass which related to deforestation and depletion respectively. Hence, renewable energy consumption plays an essential role in reducing environmental pollution over the time.

More importantly, it is found that logistic performance is statistically significant at five percent and positively affecting environmental degradation. This highlights that improvement in logistic performance may raise economic performance of firms and manufacturing activities but have harmful effects on environmental quality. Our results support the previous studies' findings of [21], [36], and [37]. According to [38] and [39], increased use of vehicles tends to produce a high level of emission and thereby leads towards unexpected changes in global ecological systems including global warming, biodiversity loss and air pollution. Besides that, logistic activities are more dangerous for environment in developing as compared to developed countries because most of the developed countries such as OECD and European countries practice green logistics operations. Therefore, in this study, we obtain an empirical support that logistic performance raises environmental degradation and lowering the levels of environmental quality in developing countries. So, we can validate the hypothesis that current logistic performance in developing countries is not enough to match the term "green logistic". Inappropriate or "ungreen" logistics performance have adverse environmental externalities, leading to environmental problems including massive emissions of greenhouse gases, pollution, noise, and waste in developing countries.

In addition, samples divided into several regions, namely Asia and the Pacific, Europe and Central Asia, Latin America and the Caribbean, South Asia and sub-Saharan Africa, to perform robustness checks. The results from the regression summarized in Table 6 . The findings from the estimated model, as shown in Table 6 have verified our expectations

\footnotetext{
7 Nevertheless, Masron and Subramaniam (2018) show that high income may still be ineffective to prevent environmental degradation if the economy suffers from serious corruption.
} 
and are still very close in Table 5. Similarly, we can conclude that the increment of logistic activities is related to the increment in the environmental degradation in the all the regions. This may tell us that the outcome of this paper provides another support to what has been found by limited past studies that logistic performance tends to lower environmental quality in developing countries. Given that the above model could be seen too simple, we further examine the model by adding several other crucial factors. The results are reported in the Appendix. In overall, the results support the finding in Table 5 and 6.

Table 6. Regression Analysis - Sub-sample [DV = LED]

\begin{tabular}{|c|c|c|c|c|c|c|c|c|c|c|}
\hline & \multicolumn{2}{|c|}{ Asia and Pacific } & \multicolumn{2}{|c|}{ Europe and Central Asia } & \multicolumn{2}{|c|}{$\begin{array}{l}\text { Latin America and } \\
\text { Caribbean }\end{array}$} & \multicolumn{2}{|l|}{ South Asia } & \multicolumn{2}{|c|}{ Sub-Saharan Africa } \\
\hline & $\begin{array}{l}\text { DIFF- } \\
\text { GMM }\end{array}$ & SYS-GMM & $\begin{array}{l}\text { DIFF- } \\
\text { GMM }\end{array}$ & SYS-GMM & $\begin{array}{l}\text { DIFF- } \\
\text { GMM }\end{array}$ & $\begin{array}{l}\text { SYS- } \\
\text { GMM }\end{array}$ & $\begin{array}{l}\text { DIFF- } \\
\text { GMM }\end{array}$ & $\begin{array}{l}\text { SYS- } \\
\text { GMM }\end{array}$ & $\begin{array}{l}\text { DIFF- } \\
\text { GMM }\end{array}$ & $\begin{array}{l}\text { SYS- } \\
\text { GMM }\end{array}$ \\
\hline$L E D_{t-1}$ & $\begin{array}{l}0.209^{* * *} \\
{[2.66]}\end{array}$ & $\begin{array}{l}0.981^{* * *} \\
{[3.94]}\end{array}$ & $\begin{array}{l}0.751^{* * *} \\
{[3.21]}\end{array}$ & $\begin{array}{l}0.884^{* * *} \\
{[3.30]}\end{array}$ & $\begin{array}{l}0.300^{* * *} \\
{[4.19]}\end{array}$ & $\begin{array}{l}0.627^{* * *} \\
{[3.41]}\end{array}$ & $\begin{array}{l}0.826^{* *} \\
{[2.27]}\end{array}$ & $\begin{array}{l}0.737^{* * *} \\
{[3.57]}\end{array}$ & $\begin{array}{l}0.422^{* * *} \\
{[2.71]}\end{array}$ & $\begin{array}{l}0.181^{* * * *} \\
{[3.41]}\end{array}$ \\
\hline$L Y$ & $\begin{array}{l}5.062^{* *} \\
{[2.32]}\end{array}$ & $\begin{array}{l}1.523^{* *} \\
{[2.25]}\end{array}$ & $\begin{array}{l}0.394 * \\
{[2.06]}\end{array}$ & $\begin{array}{l}0.021^{* * *} \\
{[2.18]}\end{array}$ & $\begin{array}{l}4.178^{*} \\
{[2.02]}\end{array}$ & $\begin{array}{l}0.056^{*} \\
{[2.02]}\end{array}$ & $\begin{array}{l}0.191^{*} \\
{[2.03]}\end{array}$ & $\begin{array}{l}0.253^{* *} \\
{[2.33]}\end{array}$ & $\begin{array}{l}0.079^{* * *} \\
{[2.51]}\end{array}$ & $\begin{array}{l}0.649^{*} \\
{[1.65]}\end{array}$ \\
\hline$L Y^{2}$ & $\begin{array}{l}-0.217^{*} \\
{[-1.84]}\end{array}$ & $\begin{array}{l}-0.277^{* * *} \\
{[-2.30]}\end{array}$ & $\begin{array}{l}-0.639^{* * *} \\
{[-3.08]}\end{array}$ & $\begin{array}{l}-0.004^{* *} \\
{[-2.28]}\end{array}$ & $\begin{array}{l}-0.179^{*} \\
{[-1.87]}\end{array}$ & $\begin{array}{l}-0.025^{* *} \\
{[-2.18]}\end{array}$ & $\begin{array}{l}-0.009 * * * \\
{[-3.03]}\end{array}$ & $\begin{array}{l}-0.018^{* * *} \\
{[-2.62]}\end{array}$ & $\begin{array}{l}-0.456^{* *} \\
{[-2.29]}\end{array}$ & $\begin{array}{l}-0.047^{* * *} \\
{[-2.55]}\end{array}$ \\
\hline$L R E$ & $\begin{array}{l}-0.101^{* *} \\
{[-2.10]}\end{array}$ & $\begin{array}{l}-0.085^{*} \\
{[-1.83]}\end{array}$ & $\begin{array}{l}-0.204^{* * *} \\
{[-2.51]}\end{array}$ & $\begin{array}{l}-0.083 \\
{[-1.38]}\end{array}$ & $\begin{array}{l}-0.048^{*} \\
{[-1.89]}\end{array}$ & $\begin{array}{l}-0.003 \\
{[-1.60]}\end{array}$ & $\begin{array}{l}-0.239 * \\
{[1.96]}\end{array}$ & $\begin{array}{l}-0.217^{*} \\
{[-1.88]}\end{array}$ & $\begin{array}{l}-0.310^{* *} \\
{[-2.22]}\end{array}$ & $\begin{array}{l}-0.214^{*} \\
{[-1.91]}\end{array}$ \\
\hline$L L P$ & $\begin{array}{l}0.320^{*} \\
{[1.99]}\end{array}$ & $\begin{array}{l}0.153^{*} \\
{[2.09]}\end{array}$ & $\begin{array}{l}0.230^{* *} \\
{[2.22]}\end{array}$ & $\begin{array}{l}0.200^{* * *} \\
{[3.03]}\end{array}$ & $\begin{array}{l}0.170^{* * *} \\
{[2.48]}\end{array}$ & $\begin{array}{l}0.395^{* * *} \\
{[2.76]}\end{array}$ & $\begin{array}{l}0.138^{* * *} \\
{[1.93]}\end{array}$ & $\begin{array}{l}0.134^{* *} \\
{[2.20]}\end{array}$ & $\begin{array}{l}0.161^{* * * *} \\
{[2.54]}\end{array}$ & $\begin{array}{l}0.091^{* * * *} \\
{[3.57]}\end{array}$ \\
\hline \multicolumn{11}{|c|}{ Model Criteria } \\
\hline Hansen & 0.617 & 0.799 & 0.143 & 0.431 & 0.135 & 0.165 & 0.498 & 0.613 & 0.484 & 0.538 \\
\hline$A R(1)$ & $0.008^{* * *}$ & $0.051^{*}$ & $0.042^{* *}$ & $0.058^{*}$ & $0.041^{* *}$ & $0.040^{* *}$ & $0.072^{*}$ & $0.018^{* *}$ & $0.073^{*}$ & $0.024^{* *}$ \\
\hline$A R(2)$ & 0.236 & 0.117 & 0.207 & 0.203 & 0.716 & 0.371 & 0.401 & 0.835 & 0.770 & 0.580 \\
\hline Diff-Sargan & & 0.999 & & 0.961 & & 0.935 & & 0.877 & & 0.967 \\
\hline
\end{tabular}

Note: Asterisks *, $* *$, and $* * *$ denotes significant at $10 \%, 5 \%$, and $1 \%$ level respectively. Figures in [ ] stand for $t$ - statistics. The values of Hansen and AR stand for $p$-value.

\section{Conclusions}

We use data from 50 countries between 2010 and 2016 to examine the relationship between logistic and environmental degradation in developing countries. The model is estimated using the dynamic panel GMM estimator. Our analysis shows that the study's core variable, the logistic performance, has a positive impact on environmental degradation. The logistical performance in the developing countries is concluded here as direct producers of environmental degradation. Supporting efforts to enhance environmental quality should, therefore, begin with efficient and sustainable logistics performance. Accordingly, the government must make it more serious in its logistics operations to use green practices, such as biofuels, environmentally-friendly vehicles or green fuel. Implementation of green practices may mitigate the extent of emission and also reduce environmental problems such as air pollution, global warming and climate change in developing countries. Secondly, it is crucial to enhance transparency, accountability, democracy and good governance to strengthen the responsibility of regulatory authority in the logistic sector. Strengthening responsibility in terms of 
implement green practices in logistic performance may create less destruction to the environmental quality. Moreover, developed countries should continue to provide financial support to developing nations for the adaption and use of green logistic to move countries to have less effect of logistic performance on environmental degradation. Therefore, developing countries need to take effective steps as well as investigate the environmental implication of investment in logistic performance and appropriate forms of policy targeting aimed at improving logistic performance and sustainable environmental management. On top of all suggestions, the most direct policy suggestion that we can ask for is the measurement of logistic performance should also take into account its negative contribution to the environment.

Moreover, this study examined only a group of selected developing countries which mixed varieties of region and income groups. Based on United Nations, Department of Economic, and United Nations, Department of Public Information (2009), the data are only available for 50 developing countries among 139 countries. Thus, the findings of these studies might be inconsistent for all the developing countries, even though it visibly explores the total picture of environmental degradation in the respect of poverty. Thereby, future researchers needed to broaden the analysis to include time series data such as for individual developing countries. This is because most of developing countries are assumed similar to each other, but in reality, these countries may have their own policies, and socio-economic characteristic. As a result, proper planning to spur sustainable environmental management and good environmental quality can be proposed strategically by evaluate those of developing economies individually.

\section{References}

[1] Khalil, N., Husin, H. N., Mahat, N., \& Nasir, N. (2011). Sustainable environment: issues and solutions from the perspective of facility managers. Procedia Engineering, 20 (1), 458-465.

[2] Marchal, V., Dellink, R., Van Vuuren, D., Clapp, C., Chateau, J., Magné, B., \& Van Vliet, J. (2011). OECD environmental outlook to 2050. Organization for Economic Co-operation and Development, 8, 397-413.

[3] Herold, D. M., \& Lee, K. H. (2017). Carbon management in the logistics and transportation sector: An overview and new research directions. Carbon Management, 8(1), 79-97.

[4] Christof, D., \&Ehrhart E. (2012). Delivering Tomorrow: Towards Sustainable Logistics. http://www.delivering-tomorrow.com

[5] Rüdiger, D., Schön, A., \& Dobers, K. (2016). Managing greenhouse gas emissions from warehousing and transshipment with environmental performance indicators. Transportation Research Procedia, 14, 886-895.

[6] World Bank (2018). World Development Indicators. Retrieved October 2019 from http://data.worldbank.org/indicator

[7] Liu, X., Zhang, K., Chen, B., Zhou, J., \& Miao, L. (2018). Analysis of logistics service supply chain for the One Belt and One Road initiative of China. Transportation Research Part E: Logistics and Transportation Review, 117 (September), 23-39.

[8] Grossman, G.M., \& Krueger, A.B. (1995). Economic growth and the environment. The Quarterly Journal of Economics, 110(2), 353-377.

[9] Selden, T.M., \& Song, D. (1994). Environmental quality and development: Is there a Kuznets curve for air pollution emissions? Journal of Environmental Economics and Management, 27(2), 147-162.

[10] Dinda, S. (2004). Environmental Kuznets curve hypothesis: A survey. Ecological Economics, 49(4), 431-455.

[11] Tamazian, A., \& Rao, B. B. (2010). Do economic, financial and institutional developments matter for environmental degradation? Evidence from tansitional economies. Energy Economics, 32(1), 137-145.

[12] Pao, H. T., \& Tsai, C. M. (2011). Multivariate granger causality between CO2 emissions, energy consumption, FDI (Foreign Direct Investment) and GDP (Gross Domestic Product): Evidence 
from a Panel of BRIC (Brazil, Russian Federation, India, and China) countries. Energy, 36(1), 685-693.

[13] Hitam, M. B., \& Borhan, H. B. (2012). FDI, growth and the environment: Impact on quality of life in Malaysia. Procedia-Social and Behavioral Sciences, 50(July), 333-342.

[14] Chen, J. H., \& Huang, Y. F. (2013). The study of the relationship between carbon dioxide (CO2) emission and economic growth. Journal of International and Global Economic Studies, 6(2), 45-61.

[15] Dogan, E., \& Seker, F. (2016). Determinants of CO2 emissions in the European Union: The role of renewable and non-renewable energy. Renewable Energy, 94(August), 429-439.

[16] Al-Mulali, U., \& Ozturk, I. (2016). The Investigation of Environmental Kuznets Curve Hypothesis in the Advanced Economies: The Role of Energy Prices. Renewable and Sustainable Energy Reviews, 54 (February), 1622-1631.

[17] Shafiei, S., \& Salim, R. A. (2014). Non-renewable and renewable energy consumption and CO2 emissions in OECD Countries: A comparative analysis. Energy Policy, 66 (March), 547-556.

[18] Bilgili, F., Koçak, E., \& Bulut, Ü. (2016). The dynamic impact of renewable energy consumption on $\mathrm{CO} 2$ emissions: a revisited environmental Kuznets curve approach. Renewable and Sustainable Energy Reviews, 54(February), 838-845.

[19] Marques, A. C., Fuinhas, J. A., \& Manso, J. P. (2010). Motivations driving renewable energy in European countries: A panel data approach. Energy policy, 38(11), 6877-6885.

[20] Ito, K. (2016). CO2 emissions, renewable and non-renewable energy consumption, and economic growth: evidence from panel data for developed countries. Economics Bulletin, 36(1), 553-559.

[21] Hazen, B. T., Cegielski, C., \& Hanna, J. B. (2011). Diffusion of green supply chain management: Examining perceived quality of green reverse logistics. The International Journal of Logistics Management, 22(3), 373-389.

[22] Aldakhil, A. M., Nassani, A. A., Awan, U., Abro, M. M. Q., \& Zaman, K. (2018). Determinants of green logistics in BRICS countries: An integrated supply chain model for green business. Journal of Cleaner Production, 195(September), 861-868.

[23] Gilley, K. M., Worrell, D. L., Davidson III, W. N., \& El-Jelly, A. (2000). Corporate environmental initiatives and anticipated firm performance: the differential effects of process-driven versus product-driven greening initiatives. Journal of Management, 26(6), 1199-1216.

[24] Pagell, M., Yang, C. L., Krumwiede, D. W., \& Sheu, C. (2004). Does the competitive environment influence the efficacy of investments in environmental management?. Journal of Supply Chain Management, 40(2), 30-39.

[25] Jacobs, B. W., Singhal, V. R., \& Subramanian, R. (2010). An empirical investigation of environmental performance and the market value of the firm. Journal of Operations Management, 28(5), 430-441.

[26] Benitez-Amado, J., Llorens-Montes, F. J., \& Fernandez-Perez, V. (2015). IT impact on talent management and operational environmental sustainability. Information Technology and Management, 16(3), 207-220.

[27] Arellano, M., \& Bond, S. (1991). Some tests of specification for panel data: Monte Carlo evidence and an application to employment equations. The Review of Economic Studies, 58(2), 277-297.

[28] Ibrahim, M.H., \& Law, S.H. (2014). Social capital and CO2 emission-output relations: A panel analysis. Renewable and Sustainable Energy Reviews, 29(January), 528-534.

[29] Arellano, M., \& Bover, O. (1995). Another look at the instrumental variable estimation of error-components models. Journal of Econometrics, 68(1), 29-51.

[30] Blundell, R., \& Bond, S. (1998). Initial conditions and moment restrictions in dynamic panel data models. Journal of Econometrics, 87(1), 115-143.

[31] Masron, T. A., \& Subramaniam, Y. (2018). The environmental Kuznets curve in the presence of corruption in developing countries. Environmental Science and Pollution Research, 25(13), 12491-12506.

[32] Jebli, M. B., \& Youssef, S. B. (2015). The environmental Kuznets curve, economic growth, renewable and non-renewable energy, and trade in Tunisia. Renewable and Sustainable Energy Reviews, 47(July), 173-185.

[33] Tiwari, A.K. and Mutascu, M. (2015) The Relationship between Environmental Degradation and Happiness in 23 Developed Contemporary Economies. Management of Environmental Quality, 26(2), 301-321.

[34] Begum, R. A., Sohag, K., Abdullah, S. M. S., \& Jaafar, M. (2015). CO2 emissions, energy consumption, economic and population growth in Malaysia. Renewable and Sustainable Energy Reviews, 41 (January), 594-601.

[35] Panayotou, T. (1997). Demystifying the environmental Kuznets curve: turning a black box into a policy tool. Environment and Development Economics, 2(4), 465-484. 
[36] Al Zaabi, S., Al Dhaheri, N., \& Diabat, A. (2013). Analysis of interaction between the barriers for the implementation of sustainable supply chain management. The International Journal of Advanced Manufacturing Technology, 68(1-4), 895-905.

[37] Benitez-Amado, J., Llorens-Montes, F. J., \& Fernandez-Perez, V. (2015). IT impact on talent management and operational environmental sustainability. Information Technology and Management, 16(3), 207-220.

[38] Hamelinck, C. N., Suurs, R. A., \& Faaij, A. P. (2005). International bioenergy transport costs and energy balance. Biomass and Bioenergy, 29(2), 114-134.

[39] Khan, S. A. R., \& Qianli, D. (2017). Impact of green supply chain management practices on firms' performance: an empirical study from the perspective of Pakistan. Environmental Science and Pollution Research, 24(20), 16829-16844.

\section{Appendix A}

We adopted those variables suggested by past studies, such as population growth (POP, De Koninck and Hai, 2016; Sarkodie, 2018; Hafeez et al., 2018), foreign direct investment (FDI, Solarin and Al-Mulali, 2018; Jiang et al., 2018; Khan and Ozturk, 2019), education (EDU, Asongu and Odhiambo, 2019; Omri et al., 2019; Masron and Subramaniam, 2019), corruption (CORR, Masron and Subramaniam, 2018; Balsalobre-Lorente et al., 2019; Akhbari and Nejati,2019) and fertilizer consumption (FERT_CONSUM, Lindau et al., 1991; Cavendish, 2000; Mozumder and Berrens, 2007; as controlled variables

Table A.1. Regression analysis for additional controlled variables [DV $=L E D]$

\begin{tabular}{|c|c|c|c|c|}
\hline & \multicolumn{2}{|c|}{ One-Step } & \multicolumn{2}{|c|}{ Two-Step } \\
\hline & DIFF-GMM & SYS-GMM & DIFF-GMM & SYS-GMM \\
\hline \multirow[t]{2}{*}{$L E D_{t-1}$} & $0.136 * * *$ & $0.988 * * *$ & $0.039 * * *$ & $0.994 * * *$ \\
\hline & [13.33] & {$[13.47]$} & {$[9.69]$} & {$[14.22]$} \\
\hline \multirow[t]{2}{*}{$\angle Y$} & 0.005 & $0.008 *$ & $0.003 *$ & $0.006 * *$ \\
\hline & {$[1.60]$} & {$[2.06]$} & {$[2.01]$} & [1.99] \\
\hline \multirow[t]{2}{*}{$\angle Y^{2}$} & $-0.048 * *$ & $-0.010 * *$ & $-0.165 * *$ & $-0.019 * *$ \\
\hline & {$[-2.25]$} & {$[-2.17]$} & {$[-2.33]$} & {$[-2.21]$} \\
\hline \multirow[t]{2}{*}{$L R E$} & $-0.017 * *$ & $-0.017 * *$ & -0.001 & $-0.002 * * *$ \\
\hline & {$[-2.14]$} & {$[-2.29]$} & {$[-1.64]$} & {$[-2.44]$} \\
\hline \multirow[t]{2}{*}{ LLP } & $0.031 * * *$ & $0.010 * *$ & $0.015 * *$ & $0.021 * *$ \\
\hline & {$[5.43]$} & {$[2.17]$} & {$[2.29]$} & {$[2.15]$} \\
\hline \multirow[t]{2}{*}{$\angle P O P$} & $0.005^{*}$ & $0.017 * *$ & $0.011 * *$ & $0.089 * * *$ \\
\hline & {$[1.95]$} & {$[2.27]$} & {$[2.15]$} & {$[3.08]$} \\
\hline \multirow[t]{2}{*}{$\angle F D I$} & $0.026 * * *$ & $0.063 * * *$ & $0.066 * * *$ & $0.025 * *$ \\
\hline & {$[3.29]$} & {$[2.50]$} & {$[4.90]$} & {$[2.28]$} \\
\hline \multirow[t]{2}{*}{ LEDU } & $-0.047 * *$ & $-0.031 * * *$ & $-0.011 * * *$ & $-0.028 * * *$ \\
\hline & {$[-2.20]$} & {$[-3.89]$} & {$[-2.89]$} & {$[-3.00]$} \\
\hline \multirow[t]{2}{*}{$\angle C O R R$} & $0.023 * * *$ & $0.054 * * *$ & $0.043 * * *$ & $0.020 * *$ \\
\hline & {$[2.96]$} & {$[2.49]$} & {$[2.83]$} & {$[2.20]$} \\
\hline \multirow[t]{3}{*}{ LFERT_CONSUM } & $0.022 * * *$ & $0.013 * *$ & $0.012 * *$ & $0.062 * * *$ \\
\hline & {$[2.65\}$} & {$[2.25]$} & {$[2.10]$} & {$[2.78]$} \\
\hline & \multicolumn{4}{|c|}{ Model Criteria } \\
\hline Hansen & 0.285 & 0.128 & 0.269 & 0.453 \\
\hline$A R(1)$ & $0.055^{*}$ & $0.008 * * *$ & $0.072 * *$ & $0.001 * * *$ \\
\hline$A R(2)$ & 0.430 & 0.770 & 0.779 & 0.707 \\
\hline
\end{tabular}




\section{Diff-Sargan}

$$
0.920
$$

0.971

Note: Asterisks $*, * *$, and $* * *$ denotes significant at $10 \%, 5 \%$, and $1 \%$ level respectively. Figures in [ ] stand for $t$ - statistics. The values of Hansen and AR stand for $p$-value. LPOP, LFDI, LEDU, LCORR and LFERT_CONSUM stand population growth, foreign direct investment, education, and corruption and fertilizer consumption.

(C) 2021 by the authors. Licensee UAIC, Iasi, Romania. This article is an open access article distributed under the terms and conditions of the Creative Commons Attribution (CC BY-NC-ND) license (https://creativecommons.org/licenses/by-nc-nd/4.0). 